ment. Thus in large measure the student is examined not by the man who gave the course. A single question may involve knowledge acquired in the work of several departments, and all questions are to be answered from this broader viewpoint and not from the viewpoint of any particular course. The grade so given on the written part of a general examination will make up 40 per cent. of the final mark for the general examination.

The oral part of each general examination will be conducted by boards of five members appointed by the committee on examinations, on each of which for the first general examination there must be at least one representative of the clinical branches, and for the second general examination at least one representative of the laboratory subjects. The board will determine by conference and vote the grade of the student, and the grade given on the oral part of a general examination will make up 20 per cent. of the final mark of the general examination.

This, then, is the plan for examination which we have voted to adopt. It is, as you see, a very considerable departure from the type of examination generally in vogue in medical schools. Practical examinations are given at present in most of the medical courses at Harvard. These will continue to be given. The present large number of written examinations will be reduced to two, to which are added tw. oral examinations, both planned to determine the student's comprehension, judgment and power rather than his detailed information. I will not occupy your time with any more minute description of the plan, and I will not enlarge upon what I consider to be its very great merits. We believe it to be a great improvement on our present system, but I will not engage in prophecy as to what it will accomplish; some years hence it can be reported again, and the reporter then will give you a criticism of its practical application with a statement of what modifications actual practise has required in it.

Henry A. Christian

Boston

\section{DR. A. R. WALLACE AND THE UNIVERSITY OF COLORADO}

IN the general biology class at the University of Colorado it is customary to give a good deal of attention to the theory of evolution, and to the history of biological science. The class (about 135 students) of this year became much interested in the character and work of Dr. Alfred Russel Wallace, and took the liberty of sending him the following greeting on the occasion of his eighty-ninth birthday:

We, the students in the general biology class at the University of Colorado, ardent admirers of your work on evolution, send you respectful greetings on the occasion of your eighty-ninth birthday, wishing you health and happiness.

To this, Dr. Wallace replied in a letter dated January 12, 1912 :

My dear Young Friends:

Thank you much for your very kind greetings. I am much pleased that so many of you are readers of my books. The wonders of nature have been the delight and solace of my life. From the day when I first saw a bee-orchis (Ophrys apifera) in ignorant astonishment, to my first view of the grand forests of the Amazon; thence to the Malay Archipelago, where every fresh island with its marvellous novelties and beauties was an additional delight-nature has afforded me an ever-increasing rapture, and the attempt to solve some of her myriad problems an ever-growing sense of mystery and awe. And now, in my wild garden and greenhouse, the endless diversities of plant life renew my enjoyments; and the ever-changing pageants of the seasons impress me more than ever in my earlier days.

I sincerely wish you all some of the delight in the mere contemplation of nature's mysteries and beauties which I have enjoyed, and still enjoy.

Yours very truly, ALFRED R. WALLACE

\section{HENRY WILSON SPANGLER ${ }^{1}$}

IN recording the death, on March 17th, of their friend and associate, Henry Wilson Spangler, Whitney Professor of Dynamical Engineering, the members of the University Faculties feel moved to give expression, how-

${ }^{1}$ Minute adopted by the faculties of the University of Pennsylvania. 